\title{
An Unusual Case of Fulminant Type 1 Diabetes Developed during Puerperium
}

\author{
P. Shihabudheen', S. K. Suresh Kumar', N. A. Uvais ${ }^{3,4, *}$ \\ 'Department of Medicine, Iqraa International Hospital and research Centre, Calicut, India \\ ${ }^{2}$ Department of Endocrinology, Iqraa International Hospital and Research Centre, Calicut, India \\ ${ }^{3}$ Department of Health Research, Iqraa International Hospital and Research Centre, Calicut, India \\ ${ }^{4}$ Department of Psychiatry, Iqraa International Hospital and Research Centre, Calicut, India
}

\section{Dear sir,}

Fulminant type 1 diabetes is a newly identified subtype of type 1 diabetes, characterized by pancreatic islet cell destruction, rapid hyperglycemia, and ketoacidosis. During the onset, the hemoglobin Alc (HbAlc) levels are normal or near-normal. Diabetic ketoacidosis (DKA) and complete $\beta$-cell destruction occur within a short period of time. The disease is more likely to develop during the third trimester of pregnancy. ${ }^{1,2)}$ The disease has not been fully characterized. It accounts for $15 \%-20 \%$ of Japanese patients with type 1 diabetes accompanied by ketosis or ketoacidosis at onset. ${ }^{3)}$ We report a rare case of fulminant type 1 diabetes that developed during puerperium.

A 20-year-old woman presented in the emergency room 1 week postpartum $\left(\mathrm{G}_{1} \mathrm{P}_{1} \mathrm{~L}_{0}\right)$ with several episodes of vomiting, labored breathing, and deterioration of consciousness. On examination, she was severely dehydrated, had cold extremities, and exhibited acidotic breathing. Investigation revealed severe DKA.

She underwent a cesarean section for gestational hypertension and uncontrolled blood sugar, which were detected on admission with labor pain. Her blood sugar and HbAlc levels were $463 \mathrm{mg} / \mathrm{dL}$ and $6.3 \%$, respectively. She had no history of gestational diabetes, and the antenatal screening results were unremarkable. Her infant developed severe hypoxic-ischemic encephalopathy, which resulted in multiple organ dysfunction syndrome and eventually, death. Upon initiating insulin therapy, her blood glucose level normalized.

During the postpartum $\mathrm{HbA1C}$ report, her doctor decided to stop insulin, and check her fasting glucose and C-peptide levels after 1 week without insulin. However, she presented to the emergency department with severe DKA after 2 days. She had a normal body mass index $\left(23.1 \mathrm{~kg} / \mathrm{m}^{2}\right)$ and unremarkable personal and family history. The laboratory findings on admission are shown in Table 1. Autoantibodies to glutamic acid decarboxylase and islet cells were negative, and the fasting C peptide was $<0.005 \mathrm{ng} / \mathrm{mL}$. She was treated for DKA. High doses of insulin were administered (>80 U/d) to attain and maintain euglycemia. The patient recovered completely. She continued receiving insulin under regular follow-up. Consent for publication of this case report was obtained from the patient.

The rapid onset and progression to severe DKA in the absence of autoantibodies and C-peptide that initially occurs during labor, despite good antenatal follow-up, favors the diagnosis of fulminant type $1 \mathrm{DM}$. The normal serum amylase level may be due to the time delay in the estimation (1 week after onset). Based on these findings, viral infection and the

Table 1. Laboratory findings at admission

\begin{tabular}{ll}
\hline \multicolumn{1}{c}{ Variable } & \multicolumn{1}{c}{ Value } \\
\hline Blood: total count & $37,400 \mathrm{cells} / \mathrm{cmm}$ \\
Differential count & $\mathrm{P} 78 \mathrm{~L} 16 \mathrm{M} 6$ \\
Casual plasma glucose & $673 \mathrm{mg} / \mathrm{dL}$ \\
Urine acetone & ++++ \\
Urine sugar & ++ \\
Arterial blood gas analysis & $\mathrm{pH}: 6.94 ; \mathrm{PaCO}_{2}: 9.5 \mathrm{~mm} \mathrm{Hg} ;$ \\
& $\mathrm{PaO}_{2}: 133 \mathrm{~mm} \mathrm{Hg} ; \mathrm{HCO}_{3}^{2}: 1.9 \mathrm{mmol} / \mathrm{L}$ \\
Liver function test & $\mathrm{Normal}$ \\
Renal function test & Normal \\
Serum electrolytes & $\mathrm{Na:} 126 \mathrm{mEq} / \mathrm{L} ; \mathrm{K}: 4.55 \mathrm{mEq} / \mathrm{L} ;$ \\
& $\mathrm{Cl}: 92 \mathrm{mEq} / \mathrm{L}$ \\
Serum amaylase & Normal \\
C-reactive protein & $3.2 \mathrm{mg} / \mathrm{dL}$ \\
\hline
\end{tabular}


subsequent immune reaction in genetically susceptible individuals cause beta-cell destruction and fulminant type 1 diabetes. ${ }^{4}$

\section{CONFLICT OF INTEREST}

No potential conflict of interest relevant to this article was reported.

\section{ORCID}

P. Shihabudheen: https://orcid.org/0000-0002-2056-1089

S. K. Suresh Kumar: https://orcid.org/0000-0002-2663-3450

N. A. Uvais: https://orcid.org/0000-0003-0961-3025

\section{REFERENCES}

1. Imagawa A, Hanafusa T, Miyagawa J, Matsuzawa Y. A novel subtype of type 1 diabetes mellitus characterized by a rapid onset and an absence of diabetes-related antibodies. Osaka IDDM Study Group. N Engl J Med 2000;342:301-7.

2. Yamamoto N, Fujita Y, Satoh S, Nakanami N, Sonoda N, Nakano H. Fulminant type 1 diabetes during pregnancy: a case report and review of the literature. J Obstet Gynaecol Res 2007;33:552-6.

3. Imagawa A, Hanafusa T, Uchigata Y, Kanatsuka A, Kawasaki E, Kobayashi T, et al. Fulminant type 1 diabetes: a nationwide survey in Japan. Diabetes Care 2003;26:2345-52.

4. Imagawa A, Hanafusa T. Pathogenesis of fulminant type 1 diabetes. Rev Diabet Stud 2006;3:169-77. 